\title{
Biogeography and morphology of a poorly known Sellaphora species
}

\author{
Éva Ács ${ }^{1,2 *}$, Carlos E. Wetzel ${ }^{3}$, Krisztina BuczKó ${ }^{4}$, Keve T. KISs $^{1}$, Katalin NAGY ${ }^{5}$, \\ Zsuzsa Trábert ${ }^{1}$, Angéla Földi ${ }^{2}$, Virág Pozderka ${ }^{6}$, Petra Werner ${ }^{7}$, David Heudre ${ }^{8}$ \\ \& Luc ECTOR ${ }^{3}$
}

${ }^{1}$ MTA Centre for Ecological Research, Danube Research Institute, 1113 Budapest, Karolina út 29, Hungary; *Corresponding author e-mail: acs.eva@okologia.mta.hu

${ }^{2}$ Sustainable Ecosystems Group, MTA Centre for Ecological Research, Klebelsberg Kuno u. 3, H-8237, Hungary

${ }^{3}$ Environmental Research and Innovation Department (ERIN), Luxembourg Institute of Science and Technology (LIST), 41 rue du Brill, L-4422 Belvaux, Luxembourg

${ }^{4}$ Hungarian Natural History Museum, Department of Botany, 1088 Budapest, Baross street 13, Hungary

${ }^{5}$ North Hungarian Inspectorate for Environmental Protection \& Nature Conservation authority, 3530 Miskolc, Mindszent tér 4, Hungary

${ }^{6}$ ELTE PhD School of Environmental Sciences, 1117 Budapest, Pázmány Péter sétány 1/A, Hungary

${ }^{7}$ Diatoms as Bioindicators, Grainauer Str. 8, 10777 Berlin, Germany

${ }^{8}$ Direction Régionale de l'Environnement, de l'Aménagement et du Logement (DREAL) Grand Est, 2 rue Augustin Fresnel, CS 57071 Metz cedex 03, France

\begin{abstract}
Specimens of a very small diatom were found in a dead oxbow of Tisza River (Hungary), in Eula River (Germany) and Parroy Pond (France). After SEM studies we identified all of them as Eolimna archibaldii J.C. TAYLOR et LANGE-BERT., which is currently regarded as endemic species to South Africa. Furthermore, the results of Principal Components Analysis of morphometric characters clearly demonstrated an overlap between the type material and European populations. Therefore this diatom cannot be considered endemic to South Africa. Moreover, E. archibaldii and a very similar species, E. becaresii are transferred to the genus Sellaphora. Our results confirm the benefit of SEM for verifying the identity of small-sized diatoms, especially for routine monitoring, and allow more precise ecological assessment.
\end{abstract}

Key words: biomonitoring, endemism, Eolimna, new combination, small diatoms, type material, Water Framework Directive

\section{INTRODUCTION}

In European countries, several biological elements are obligatory for monitoring the ecological status of fresh waters according to the European Water Framework Directive (WFD). Diatoms are one of these elements and routine monitoring is performed using light microscopy (LM). The identification of dominant species is therefore crucial for obtaining unbiased results.

Small naviculoid diatoms frequently dominate in fresh water and when their relative abundance exceeds $5 \%$, their ecological importance is unquestionable (Wetzel et al. 2015). However, whereas most of them can hardly be identified at species level using (LM) European ecological status assessments require identification to the highest taxonomical level possible (The European Parliament and the Council of the EUROPEAN UNION 2000) and the commonly used diatom metrics work at species level or below (ECTOR \& RIMET 2005).

During the Hungarian surveillance monitoring programme, a small, rhombic diatom was found as a dominant species (with a relative abundance of $18 \%$ ) in an oxbow of Tisza River (Kanyari Holt-Tisza near Kisköre) in 2011. This small, rhombic diatom was unidentifiable by LM due to its diminutive size and the difficulty of visualising the striation pattern; no exact match could be found with taxa in widely used diatom identification books (Krammer \& Lange-Bertalot 1986; Hofmann et al. 2011; Bey \& Ector 2013). Similar diatoms were found in the Eula River, Germany and in Parroy Pond, France. We studied all three populations in more detail, as they showed a morphological resemblance to taxa of several different genera including Craticula subminuscula (Manguin) C.E. Wetzel et Ector in Wetzel et al., Fallacia indifferens (Hust.) 
D.G. MAnN in Round et al., Lacuneolimna zalokariae (Lange-Bert. et Metzeltin) Tudesque, Le Cohu et LANge-Bert. in Tudesque et al., Navicula confusa Laslandes et Kociolek, Navicula mucicoloides Hust., Navicula microrhombus (CHOLnOKy) Schomman et R.E.M. ARChibALD and Navigiolum adamantiforme (R.E.M. Archibald) J.C. TaYlor et Lange-Bert., Sellaphora chistiakovae (KULIKOVSKIY et LANGE-BERT.) C.E. Wetzel, Ector, VAn DE ViJver, Compère et D.G. MAnn and Sellaphora madida (Kociolek) C.E. Wetzel in Wetzel et al. However, they were consistently smaller than most of the species mentioned above. In 2015 a few specimens of the same small diatom were found in two more locations in France.

Our main goal was to identify these small and dominant diatoms. Here we give the results of scanning electron microscopy (SEM) studies of this small naviculoid European species and compared the European material with the South African type material of EOlimna archibaldii.

\section{Material And Methods}

Site description. In Hungary, a sample was taken in August 2011 from Kanyari Holt-Tisza, which is situated between Kisköre and Pély. Kanyari Holt-Tisza is an alkaline, eutrophic oxbow of the River Tisza with elevated electrolyte content (Table 1). Its catchment area is $7.19 \mathrm{~km}^{2}$ and the surface area is 54 ha, $50 \%$ of the water surface was covered by sedge (Carex sp.) and reed (Phragmites australis (CAV.) TRIN. ex STEUd.) on the sampling time. In Germany, the samples were taken from Eula River, below Geithain, in the district of Le- ipzig, Saxony, in October 2014. The River Eula is a calcareous, clay-rich, upland river with fast flow and moderate turbulence (Table 1).

The principal French population studied came from the phytoplankton of Parroy pond (Etang du Parroy, near Nancy, north-eastern France) in August 2011 and July 2014. Parroy Pond is an artificial waterbody created in the late $19^{\text {th }}$ century on chalky bedrock to serve as a reservoir for the Marne to Rhine canal. Its maximum depth is $4.3 \mathrm{~m}$. The largest population was collected in July 2014, when dissolved organic carbon (DOC) was $23 \mathrm{mg} . \mathrm{l}^{-1}$ and biochemical oxygen demand $\left(\mathrm{BOD}_{5}\right)$ was $3.3 \mathrm{mg} . \mathrm{l}^{-1}$ (see additional chemistry in Table 1).

Additional French samples were collected from stones in October 2015 from two lakes, Mare à Goriaux $\left(50^{\circ}\right.$ $\left.23^{\prime} 42^{\prime \prime} \mathrm{N}, 3^{\circ} 25^{\prime} 58^{\prime \prime E}\right)$ and Étang du Vignoble $\left(50^{\circ} 20^{\prime} 42^{\prime \prime} \mathrm{N}, 3^{\circ}\right.$ 29'53"E), situated near Valenciennes, Hauts-de-France Region, France (water chemical data are not available).

Collection, preparation and investigation of samples. Phytobenthos samples were collected from green reed stems in Kanyari Holt-Tisza, Hungary. Stems were chosen randomly and $20 \mathrm{~cm}$ sections were cut with clippers starting at $10 \mathrm{~cm}$ below the water surface. Stem sections were placed in plastic bags and transported to the laboratory, where epiphyton was removed using a stiff brush and tap water. In the case of Eula River, periphyton was sampled across the river bed from silt, sand and stones, along a 100 meter stretch; material from the different substrata was combined into one bottle and alcohol was added. Together, these three substrata covered about $60 \%$ of the river-bed. The frustules were cleaned with hydrochloric acid and hydrogen peroxide, subsequently washed in distilled water, and mounted with Naphrax ${ }^{\circledR}$ mounting medium (CEN 2003). Diatoms were investigated using an Olympus ${ }^{\circledR}$ IX70 inverted microscope equipped with differential interference contrast (DIC) optics (Hungarian sample),

Table 1. Environmental variables of sampling sites. The small diatom taxon contributed the given relative abundance (\%) to the diatom assemblage.

\begin{tabular}{|c|c|c|c|}
\hline & $\begin{array}{l}\text { Kanyari Holt- } \\
\text { Tisza }\end{array}$ & Eula River & Parroy pond \\
\hline Country & Hungary & Germany & France \\
\hline Latitude & $\mathrm{N} 47^{\circ} 29^{\prime} 21.20^{\prime \prime}$ & N $51^{\circ} 02^{\prime} 10.06^{\prime \prime}$ & N 48 $40^{\circ} 47.96^{\prime \prime}$ \\
\hline Longitude & E $20^{\circ} 26^{\prime} 59.68^{\prime \prime}$ & E $12^{\circ} 42^{\prime} 34.22^{\prime \prime}$ & E 6 $34^{\prime} 59.95^{\prime \prime}$ \\
\hline Water body & oxbow lake & river & artificial pond \\
\hline Average water depth (spring/fall) (m) & $\sim 2 / \sim 0.9$ & $0.3-1$ & 2.1 \\
\hline Water temperature $\left({ }^{\circ} \mathrm{C}\right)$ & 22 & 15.5 & 20.7 \\
\hline pH & 7.8 & 8.1 & 8.4 \\
\hline Electric conductivity (EC) $\left(\mu \mathrm{S} \mathrm{cm}^{-1}\right)$ & 1418 & 614 & 801 \\
\hline Total organic carbon (TOC) $\left(\mathrm{mg} . \mathrm{l}^{-1}\right)$ & 12.4 & 3.4 & 5.3 \\
\hline Dissolved oxygen (DO) $\left(\mathrm{mg} . \mathrm{l}^{-1}\right)$ & 4.2 & 6.3 & 7.5 \\
\hline Orthophosphate-phosphorous $\left(\mathrm{PO}_{4}-\mathrm{P}\right)\left(\mu \mathrm{gg} . \mathrm{l}^{-1}\right)$ & 91.5 & 79 & 108.3 \\
\hline Total phosphorous (TP) $\left(\mu \mathrm{g} . \mathrm{l}^{-1}\right)$ & 520 & 1100 & 150 \\
\hline Relative abundance of studied small diatom (\%) & 18 & 20 & 9 \\
\hline
\end{tabular}


a Zeiss ${ }^{\circledR}$ Axio Scope with DIC (German sample), and a Leica ${ }^{\circledR}$ DMRX (French sample). For SEM studies a part of the cleaned and washed samples was filtered through a $3 \mu \mathrm{m}$ Isopore $^{\mathrm{TM}}$ polycarbonate membrane filter (Merck Millipore), which was fixed onto a stub using double-sided carbon tape, and coated with gold. The fine structure of the diatom was observed with Zeiss EVO MA 10 SEM operated at $15 \mathrm{kV}$ and $10 \mathrm{~mm}$ distance in case of Hungarian and German samples using SE and STEM detectors.

The type material of Eolimna archibaldii J.C. TAYLOR et LANGE-BERT. (Vaal River from Klipplaatdrift (2720'46"S, $26^{\circ} 25^{\prime} 50^{\prime \prime E}$ ), Free State Province, South Africa, coll. Date 15 March 2002), sample NWU 03-083 (deposited at the North-West University Diatom Collection, School of Environmental Sciences, Potchefstroom Campus, North-West University, South Africa) was observed. The material had been collected from stones with a small brush and the resultant suspension placed in a $150 \mathrm{ml}$ plastic sample bottle; later, a portion of the sample was oxidised by boiling in a mixture of 2:1 nitric and sulphuric acid, and rinsed (TAYLOR \& LANGE-Bertalot 2006). Cleaned and rinsed samples were mounted on permanent slides with Naphrax ${ }^{\circledR}$. LM observations and morphometric measurements were performed using a Leica ${ }^{\circledR}$ DMRX brightfield microscope with $100 \times$ oil immersion objective and light micrographs were taken with a Leica ${ }^{\circledR}$ DC500 camera. For SEM observations the cleaned samples were filtered with additional deionized water through a 3- $\mu \mathrm{m}$ Isopore ${ }^{\mathrm{TM}}$ polycarbonate membrane filter (Merck Millipore). Filters were mounted on aluminium stubs and coated with platinum using a Modular High Vacuum Coating System BAL-TEC MED 020 (BAL-TEC AG, Balzers, Liechtenstein). An ultrahigh-resolution analytical field emission (FE) scanning electron microscope Hitachi SU-70 (Hitachi High-Technologies Corporation, Japan) operated at $5 \mathrm{kV}$ and $10 \mathrm{~mm}$ distance was used for the analysis. SEM images were taken using the lower (SE-L) and upper (SE-U) detector signal. Micrographs were digitally manipulated and plates containing LM and SEM images were created using CorelDraw X6.

Morphometric analysis. The length and width of valves were measured using tpsDig2 software (RoHLF \& SLICE 1990; RoHLF 2004). We used only the SEM images for more precise measuring. Shapiro-Wilk tests were carried out to test the normality of metrics. One-way ANOVA was performed

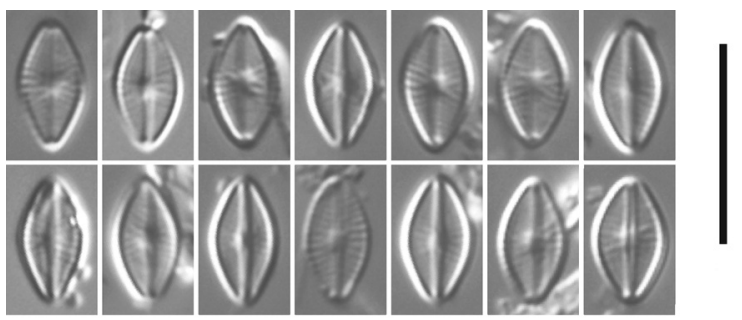

\section{1-14}
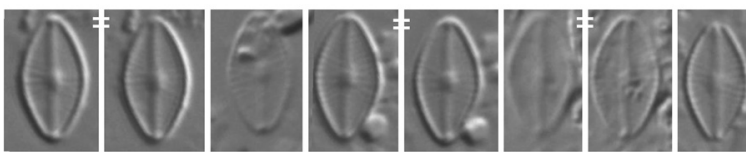

15-22

Figs 1-22. Sellaphora archibaldii comb. nov. LM images: (1-14) Kanyari Holt-Tisza, Hungary (15-22) Eula River, Germany. to test, if the means of the length (L), width (W) and L/W ratio of valves differed significantly among the populations (the Kruskal-Wallis test was used when the metrics did not assume normal distributions). When the ANOVA or Kruskal-Wallis showed significant inequality of the means, post hoc pairwise tests (Tukey's and Mann-Whitney pairwise comparisons) were carried out. Principal component analysis (PCA) was applied to the morphometric characteristics (L, W and $\mathrm{L} / \mathrm{W}$ ratio). The tests were calculated with software Past version 1.78 (HAMMER et al. 2001).

\section{RESUlts}

\section{Observations \\ Light and electron microscopic studies of European samples}

In LM (Figs 1-22), the valves were rhombic-lanceolate to rhombic-elliptic with acutely rounded apices. In practice, only the raphe, the prominent central nodule and helictoglossae were visible in our material, unless we used the very best optics, when we could see a fine radial striation in the central part. The axial area is narrow and linear. The central area is small. Valve length $=5.4-6.4 \mu \mathrm{m}$ (mean: $6.0 \mu \mathrm{m}$, SD: 0.22), valve width $=2.5-3.4 \mu \mathrm{m}$ (mean: $3.0 \pm 0.18 \mu \mathrm{m})$. The $\mathrm{L} / \mathrm{W}$ ratio is 1.8-2.1 (mean: $1.98 \pm 0.08 \mu \mathrm{m} ; \mathrm{n}=62$ ).

SEM (Figs 23-31) revealed that the striae are radiate, alternately short and long around the central nodule, and composed of single rows of areolae; hymenes are present in a median position countersunk in the areolae (Figs 28-29). The stria density is not particularly high (32-36 striae/10 $\mu \mathrm{m})$ despite the difficulty of visualizing the striae in LM; there are 70-80 areolae $/ 10 \mu \mathrm{m}$. The external raphe fissure is gently curved and located proximally in a slightly raised sternum (Fig. 29). The central raphe endings are slightly deflected to the primary valve side (Figs 23-24, 27-29), while the terminal endings are deflected to the secondary side and elongated onto the valve mantle (Figs 24, 28-29). Internally, the raphe fissure is straight and the central endings are slightly deflected towards the primary side (Figs 26, 30-31). The raphe terminates at the poles in small helictoglossae (Figs 25, 30-31). One series of single poroids on the mantle (Fig. 28) is in line with striae. According to the electron microscope studies this small naviculoid diatom is similar to Eolimna archibaldii J.C. TAYLOR et LANGE-BERT. (TAYLOR \& LANGE-BERTALOT 2006).

\section{Comparison of European specimens with type ma- terial of Eolimna archibaldii}

Type material of E. archibaldii is shown in Figs 32-36. The valves are rhombic-lanceolate to rhombic-elliptic with acutely rounded apices. The valve length is 5.3$5.9 \mu \mathrm{m}$ (mean: $5.5 \mu \mathrm{m}, \mathrm{SD}: 0.3$ ), valve width $2.8-3.3$ 
$\mu \mathrm{m}$ (mean: 3.0, SD: 0.15 ), and the $\mathrm{L} / \mathrm{W}$ ratio is $1.7-2.0$ (mean: 1.85, SD: 0.1). These values overlap with those for the Hungarian, German and French populations (Fig. 37).

Apart from the L/W ratio of the German population, the metrics (length, width, L/W) have a normal distribution (Table 2). In most cases the $p$ values of Tukey's and Mann-Whitney tests were not significant. Hence the samples can be assumed to have been taken from populations with equal means, but in several cases the values were significant in comparison of some other populations, so in this case we cannot say that the samples were taken from populations with equal means (Table 3). However the results of the PCA of morphometric characters clearly demonstrated an overlap between the type material and Hungarian, German and French populations along the first and second PC axes (Fig. 38). PCA revealed that the first two factors explain almost all the variability $(99.7 \% ; \lambda 1=56.4 \%$, $\lambda 2=43.3 \%$ ) in the correlation matrix. Furthermore after the SEM studies we can say that European studied populations without doubt belong to $E$. archibaldii.

\section{Discussion}

The Hungarian, German and French populations studied are identical with South African type material of Eolimna archibaldii and can be assigned to it without any doubt, based on examination with SEM (Figs 23-36) and the results of morphometric analysis (Figs 37-38). In Europe the species was found in alkaline, eutrophic water with elevated electrolyte content, just as in South Africa (TAYlor \& LANGe-Bertalot 2006; TAYLOR et al. 2007b).

Wetzel et al. (2015) evaluated generic boundaries and concepts of Eolimna and Sellaphora (and also the catch-all genus Naviculadicta) and concluded that there appear to be no clear differentiation between extant species of these genera. Several molecular studies have also shown that some former Eolimna species belong to the genus Sellaphora (e.g. Novis et al. 2012; ZGRUNDO et al. 2013; KULIKOvSKIY et al. 2014), forming a monophyletic group. Wetzel et al. (2015) proposed the transference of several Eolimna, Naviculadicta, and Navicula s.l. taxa into Sellaphora and further Eolimna species have been transferred to Sellaphora by Beauger et al. (2016). However, not all Eolimna species should be transferred to Sellaphora. The former Eolimna subminuscula belongs to Craticula according to molecular results (ZGRUNDO et al. 2013), and in agreement with this Craticula (Eolimna) subminuscula has parallel striation, which is one of the most characteristic features of Craticula. Moreover a distant relationship between Eolimna subminuscula and E. minima was shown also by BESZTERI et al. (2001) based on SSU rDNA.

Judging by morphological characteristics such as the presence of uniseriate striae, a central and straight raphe with slightly deflected proximal ends; the presence of distal raphe ends with helictoglossae, and the above mentioned molecular evidence linking Eolimna to Sellaphora, we propose the transfer of E. archibaldii to the genus Sellaphora as follows.

\section{Sellaphora archibaldii (J.C. TAYLOR et LANGE-BERT.) Ács, C.E. Wetzel et Ector comb. nov. \\ Basionym: Eolimna archibaldii J.C. TAYLOR et LANGE-Bert. 2006, African Journal of Aquatic Science, vol. 31 (2), p. 178, fig. 3(a-y).}

In 2009 a very similar species, Eolimna becaresii S. BLANCO et ECTOR, was described from the shallow Lake Constanzana in Spain (BlAnco et al. 2009). The main difference between $E$. becaresii and $S$. archibaldii is the $\mathrm{L} / \mathrm{W}$ ratio, which is more or equal to 2.2 for $E$. becaresii but less than 2.2 for $S$. archibaldii. GeITLER (1932) showed that in pennate diatoms length reduces much more strongly than width during the life cycle, so probably the L/W ratios cannot be used for taxon separation. Moreover conspecificity between S. archi-

Table 2. $p$-values of Shapiro-Wilk test between different populations of Eolimna archibaldii (bold: significant).

\begin{tabular}{lcccc}
\hline & Type & Hungarian & German & French \\
\hline Length & 0.66 & 0.1 & 0.48 & 0.11 \\
Width & 0.16 & 0.39 & 0.28 & 0.52 \\
L/W & 0.09 & 0.61 & $\mathbf{0 . 0 0 0 1}$ & 0.41 \\
\hline
\end{tabular}

Table 3. p-values of Tukey's and Mann-Whitney pairwise comparisons between different populations of Eolimna archibaldii (bold: significant).

\begin{tabular}{lrrrrrr}
\hline & Type-Hung. & Type-Germ. & Type-Fren. & Hung.-Germ. & Hung-Fren. \\
\hline Length Tukey's test & $\mathbf{0 . 0 0 3}$ & $\mathbf{0 . 0 0 0 2}$ & $\mathbf{0 . 0 0 0 2}$ & $\mathbf{0 . 0 3}$ & 0.7 \\
Width Tukey's test & 0.74 & 0.1 & 0.94 & 0.55 & 0.39 \\
L/W Mann-Whitney test & 0.11 & $\mathbf{0 . 0 4}$ & $\mathbf{0 . 0 0 0 6}$ & 0.86 & 0.11 \\
\hline
\end{tabular}



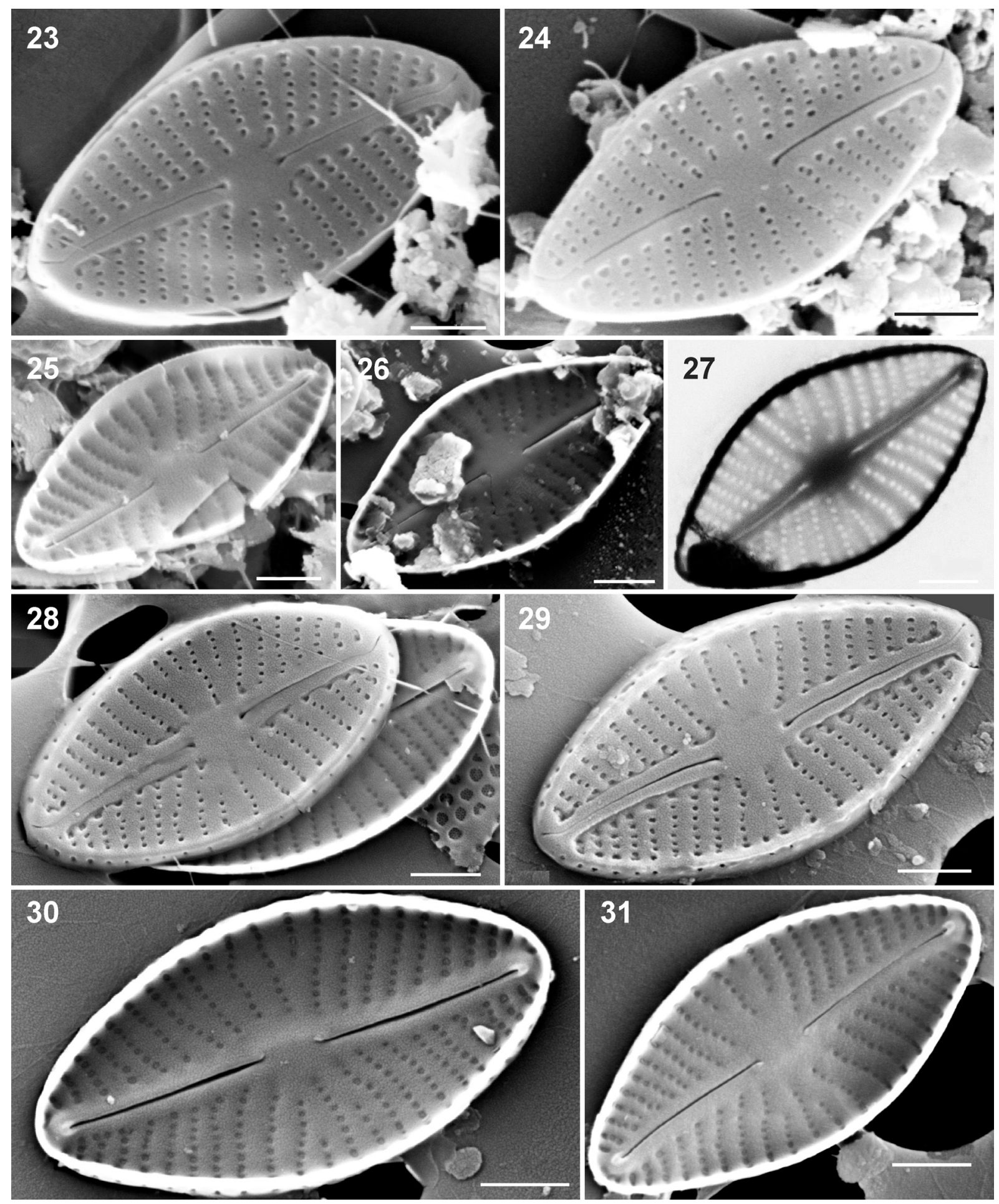

Figs 23-31. Sellaphora archibaldii comb. nov. EM images: (23-27) Kanyari Holt-Tisza, Hungary, (28-31) Eula River, Germany; SEM external view: (23-24, 28-29), SEM internal view: (25-26, 30-31), TEM: (27).

baldii and E. becaresii cannot be discarded as a possibility since many other ultrastructural morphological characters overlap and are even identical. For the moment, however, we adopt the conservative strategy of maintaining E. becaresii as a separate species, while transferring it to Sellaphora because of its morphological similarity to $S$. archibaldii and other small-celled Sellaphora species:
Sellaphora becaresii (S. BLANCo et ECTOR in BLANCO et al.) C.E. Wetzel, Ács et Ector comb. nov.

Basionym: Eolimna becaresii S. Blanco et Ector in Blanco et al. 2009, Diatom Research, vol. 24 (2), p. 490-491, figs 2-54.

Sellaphora archibaldii is morphologically similar to other small naviculoid species in LM, particularly in valve shape. In relation to LM features, $S$. archibal- 

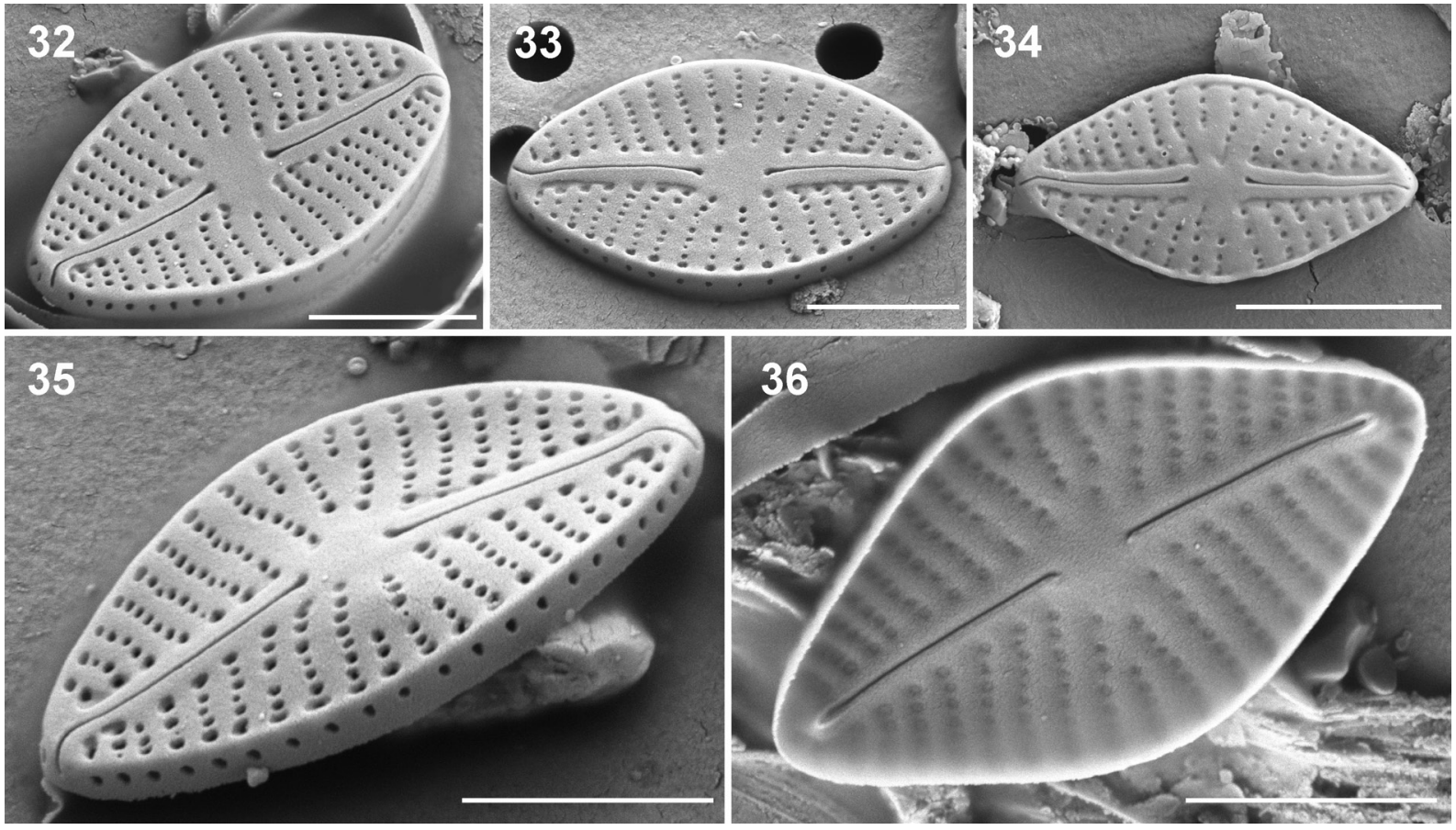

Figs 32-36. Sellaphora archibaldii comb. nov., SEM images from the South African type material (MWU 03-083): (32-35) external view, (36) internal view.

dii is shorter than Craticula subminuscula, Sellaphora chistiakovae, Lacuneolimna novagallia, L. zalokariae and Navicula mucicoloides; and narrower than $S$. chistiakovae, L. novagallia, L. zalokariae, Navicula microrhombus, $N$. mucicoloides and Navigiolum adamantiforme (Supplementary Table S1).

In LM, the valve morphology (shape, length, width) of Sellaphora archibaldii overlaps with Sellaphora madida, Fallacia indifferens and Navicula confusa, but the fine structure shows clear differences. The central area of Sellaphora madida is accompanied towards the margin by four shortened striae, while $S$. archibaldii has two shortened striae in the central area. The striae of Fallacia Stickle et D.G. MANN are covered externally by finely porous conopea (Round et al. 1990), while Eolimna and Sellaphora do not have conopea. The striae are composed of lineolae (linear areolae, aligned longitudinally) in the genus Navicula, while Eolimna and Sellaphora have either single or double rows of round areolae (SCHILLER \& LANGE-BeRTALOT 1997; Round et al. 1990). Moreover Navicula confusa has significantly less striae (20-26 in $10 \mu \mathrm{m})$, than $S$. archibaldii.

Eolimna archibaldii was described from Vaal River, South Africa by TAYlor \& Lange-Bertalot (2006), but the first known occurrence of the species was in 2002, when it was found as a dominant species (relative abundance of 47.7\%) in March 2002 at Klipplaatdrift, where the water temperature varied between 10 and $29^{\circ} \mathrm{C}$ (median $23^{\circ} \mathrm{C}$ ). It was also found with lower abundance in Wilfe River in April 2002 (as Eolimna sp. in TAYLOR 2004).
Until now, it had been thought that Eolimna archibaldii may be endemic to South Africa (TAYLOR et al. 2007a, b). Before our observations, this species had not been recorded in other countries, but after the new records (Fig. 39) presented here we can establish that it is not an endemic diatom species for South Africa. Our data presented are a demonstration of the caution that needs to be exercised in concluding that any freshwater diatom either is an endemic, or has a disjunct distribution, or has been introduced. There are several reasons for failure to record a diatom in a particular area. One possible reason is under-sampling. Another is confusion with other similar taxa. In our case confusion with other similar taxa in LM studies is likely. Furthermore, we cannot reject the possibility that diatoms might at times be transported outside their native range through human activities (MANN 2015), i.e. that species like $S$. archibaldii may originally have been endemic but have become more widely distributed in recent years.

According to our results, we suggest the verification of small-celled diatoms using electron microscopy in the future, even in routine monitoring, especially if they are very abundant in the sample, to get better results for ecological assessment. To study small well-known and widely distributed diatoms with SEM is also of taxonomical importance (Wetzel et al. 2015).

It would be valuable in the future to complete the morphological studies reported here with molecular ones to determine the taxonomical distance between small naviculoid species with only slight microstructural differences, as in the case of Sellaphora archibaldii and S. becaresii. And finally, whatever the 

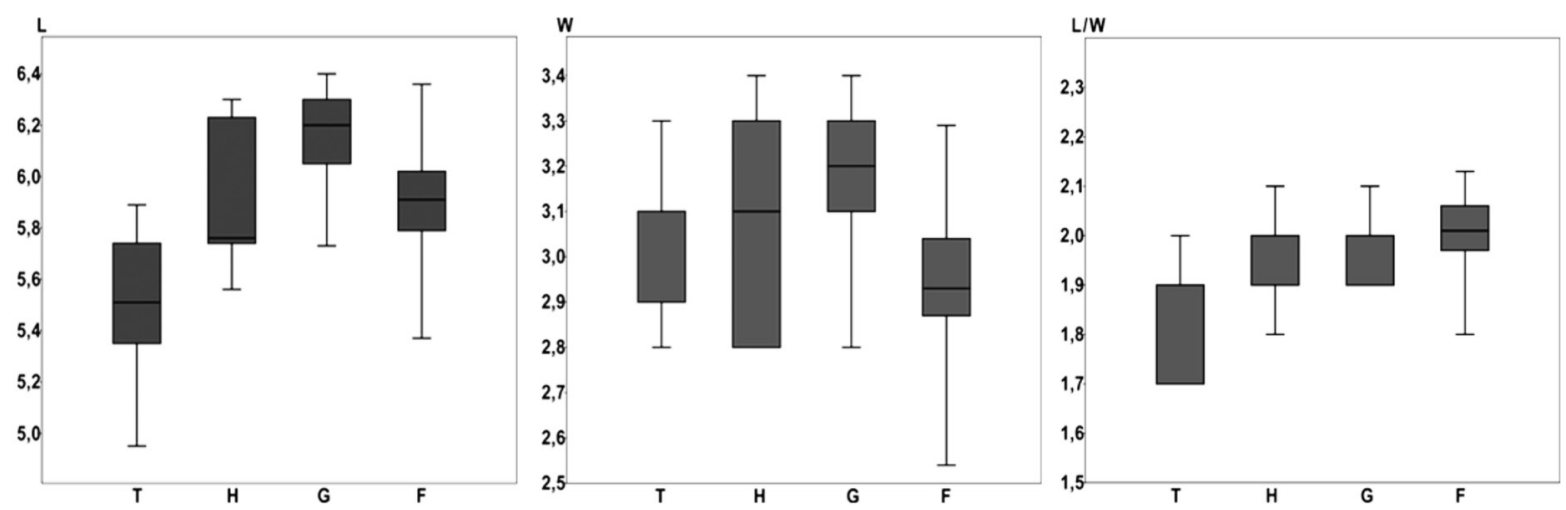

Fig. 37. Boxplots of length (L), width (W) and length:width ratio (L/W) measurements of type material of Sellaphora archibaldii (T), as well as from Hungarian $(\mathrm{H})$, German $(\mathrm{G})$ and French $(\mathrm{F})$ populations.

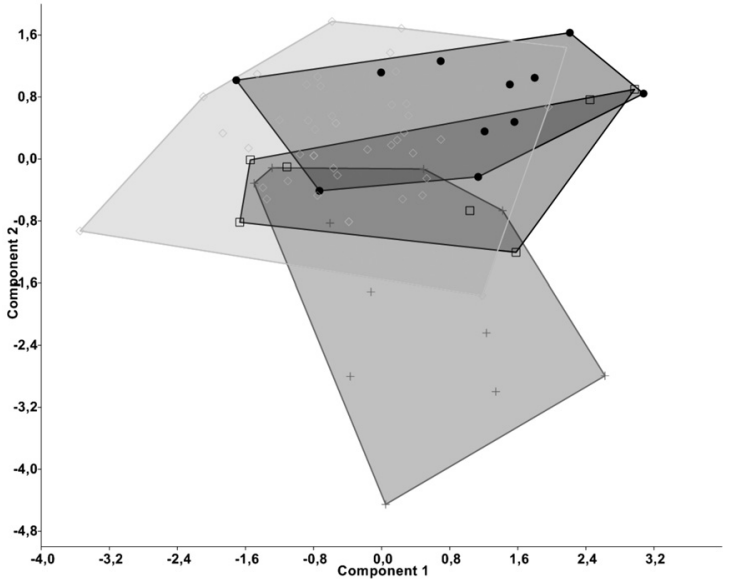

Fig. 38. Plot of principal component scores 1 and 2, based on the morphometric dataset of South African type material of Sellaphora archibaldii (cross), Hungarian (square), German (black circle) and French (diamond) populations.

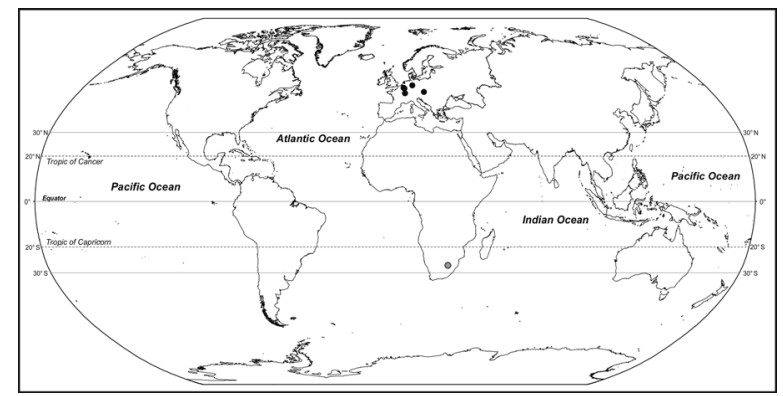

Fig. 39. Distribution records of Sellaphora archibaldii. Type locality of $S$. archibaldii (grey dot) is indicated as well.

consensus adopted concerning generic boundaries, the most important issue from the practical point of view, is the circumscription of Sellaphora archibaldii, which is found commonly in several European waters.

\section{ACKNOWLedgements}

The authors are thankful to Diba Khan-Bureau (Department of Natural Resources and the Environment, University of Connecticut,
USA) for her precious English corrections, Jonathan Taylor (School of Biological Sciences, North-West University, Potchefstroom, South Africa) for sending the type material of Eolimna archibaldii, David Fouré (DREAL Hauts-de-France), Laura Moreau (DREAL Lorraine) and Nathalie Zydek (DREAL Hauts-de-France) for the samples collected in several lakes of France, the Saxon State Company for Environment and Agriculture (BfUL), Germany, for collecting the German samples and the Saxon State Office for Environment, Agriculture and Geology (LfULG), Germany, for providing the German diatom material and site information including the chemical data. Funding was partially provided by the Luxembourg Institute of Science and Technology (LIST, TAXODIA project) and by Hungarian GINOP-2.3.2-15-2016-00019 project. We thank the reviewers for their helpful comments and corrections.

\section{REFERENCES}

Beauger, A.; Wetzel, C.E.; Voldoire, O.; Garreau, A. \& EcTOR, L. (2016): Sellaphora labernardierei (Sellaphoraceae, Bacillariophyta), a new epilithic species from French spring and four new combinations within the genus Sellaphora. - Phytotaxa 260: 235-246.

Beszteri, B.; Ács, É.; Makk, J.; Kovács, G.; Márialigeti, K. \& KIss, K.T. (2001): Phylogeny of six naviculoid diatoms based on $18 \mathrm{~S}$ rDNA sequences. - Int. J. Syst. Evol. Microbiol. 51: 1581-1586.

Bey, M.-Y. \& Ector, L. (2013): Atlas des diatomées des cours d'eau de la région Rhône-Alpes. Tome 1 Centriques, Monoraphidées. Tome 2 Araphidées, Brachyraphidées. Tome 3 Naviculacées: Naviculoidées. Tome 4 Naviculacées: Naviculoidées. Tome 5 Naviculacées: Cymbelloidées, Gomphonématoidées. Tome 6 Bacillariacées, Rhopalodiacées, Surirellacées. $-1182+27$ pp., Direction régionale de l'Environnement, de l'Aménagement et du Logement Rhône-Alpes, Lyon, http://www.rhone-alpes.developpement-durable.gouv.fr/atlas-des-diatomeesde-la-region-a3480.html

Blanco, S.; Novais, M.H.; HoffMann, L. \& Ector, L. (2009): Eolimna becaresii sp. nov., a new diatom taxon from a Spanish shallow lake. - Diatom Res. 24: 487-494.

CEN (2003): Water quality - guidance standard for the routine sampling and pretreatment of benthic diatoms from rivers. EN 13946: 2003. - 14 pp., Comité Européen de Normalisation, Geneva.

ECTOR, L. \& RiMET, F. (2005): Using bioindicators to assess 
rivers in Europe: An overview. In: LEK, S.; SCARDI, M.; Verdonschot, P.F.M.; Descy, J.P. \& Park, Y.S. (eds): Modelling Community Structure in Freshwater Ecosystems. - pp. 7-19, Springer-Verlag, Berlin Heidelberg.

Geitler, L. (1932): Der Formwechsel der pennaten Diatomeen (Kieselalgen). - Arch. Protistenk. 78: 1-226.

Hammer, Ø.; Harper, D.A.T. \& Ryan, P.D. (2001): PAST: Paleontological statistics software package for education and data analysis. - Palaeontol. Electron. 4: art. 4, 9 pp.

Hofmann, G.; Werum, M. \& Lange-Bertalot, H. (2011): Diatomeen im Süßwasser-Benthos von Mitteleuropa. Bestimmungsflora Kieselalgen für die ökologische Praxis. Über 700 der häufigsten Arten und ihre Ökologie. -908 pp., A.R.G. Gantner, Ruggell.

Hustedt, F. (1942): Süßwasser-Diatomeen des indomalayischen Archipels und der Hawaii-Inseln. - Int. Rev. ges. Hydrobiol. Hydrogr. 42: 1-252.

Kociolek, J.P.; Laslandes, B.; Bennett, D.; Thomas, E.; Brady, M. \& GraefF, C. (2014): Diatoms of the United States 1. Taxonomy, ultrastructure and descriptions of new species and other rarely reported taxa from lake sediments in the Western U.S.A. - In: Lange-Bertalot, H. \& Kociolek, J.P. (eds): Bibliotheca Diatomologica, vol. 61. - 188 pp., J. Cramer, Gebrüder Borntraeger, Stuttgart.

Krammer, K. \& LAnge-Bertalot, H. (1986): Bacillariophyceae. 1. Teil: Naviculaceae. - In: ETTL, H.; GÄrTNER, G.; Gerloff, J.; Heynig, H. \& Mollenhauer, D. (eds): Süßwasserflora von Mitteleuropa, vol. 2/1 876 pp., Gustav Fischer Verlag, Stuttgart.

Kulikovskiy, M.S.; Lange-Bertalot, H. \& Witkowski, A. (2010): Diatom flora of Polistovo-Lowatski Sphagnum tract (European Russia). I. Eolimna chistiakovae sp. nov. and further transfers to the genus Eolimna Lange-Bertalot \& Schiller. - Diatom Res. 25: 77-85.

Kulikovskiy, M.S.; Gusev, E.; Andreeva, S. \& Annenkova, N. (2014): Phylogenetic position of the diatom genus Geissleria Lange-Bertalot \& Metzeltin and description of two new species from Siberian mountain lakes. - Phytotaxa 177: 249-260.

MANN, D.G. (2015): Are there any alien marine diatoms? Eur. J. Phycol. 50 sup 1: 91.

Moser, G.; Lange-Bertalot, H. \& Metzeltin, D. (1998): Insel der Endemiten Geobotanisches Phänomen Neukaledonien (Island of endemics New Caledonia - a geobotanical phenomenon). - In: LANGE-BERTALOT, H. \& KocIoleK, J.P. (eds): Bibliotheca Diatomologica, vol. 38. - 464 pp., J. Cramer, Gebrüder Borntraeger, Berlin \& Stuttgart.

Novis, P.M.; Braidwood, J. \& Kilroy, C. (2012): Small diatoms (Bacillariophyta) in cultures from the Styx River, New Zealand, including descriptions of three new species. - Phytotaxa 64: 11-45.

RoHLF, F.J. (2004): TpsDig, digitize landmarks and outlines, version 2.0. - Department of Ecology and Evolution, State University of New York at Stony Brook. http:// life.bio.sunysb.edu/morph/

Rohlf, F.J. \& Slice, D. (1990): Extensions of the Procrustes method for the optimal superimposition of landmarks. - Syst. Zool. 39: 40-59.

Round, F.E.; Crawford, R.M. \& Mann, D.G. (1990): The diatoms. Biology and morphology of the genera. 747 pp., Cambridge University Press, Cambridge.
Schiller, W. \& Lange-Bertalot, H. (1997): Eolimna martinii n.gen., n.sp. (Bacillariophyceae) aus dem UnterOligozän von Sieblos/Rhon im Vergleich mit ähnlichen rezenten Taxa. - Paläont. Z. 71: 163-172.

Schoeman, F.R. \& Archibald, R.E.M. (1977): The Diatom Flora of Southern Africa. $n^{\circ} 3$. CSIR Special Report WAT 50 - 61 pp., National Institute for Water Research, Council for Scientific and Industrial Research, Pretoria.

TAYLOR, J.C. (2004): The application of diatom-based pollution indices in the Vaal catchment [MSc. Dissertation]. - 192 pp., Potchefstroom Campus, North-West University.

TAYlor, J.C. \& LANGe-Bertalot, H. (2006): Eolimna archibaldii spec. nov. and Navigiolum adamantiforme comb. nov. (Bacillariophyceae): two possibly endemic elements of the South African diatom flora tolerant to surface water pollution. - Afr. J. Aquat. Sci. 31: 175-183.

TaYlor, J.C.; Harding, W.R. \& Archibald, G.M. (2007a): An Illustrated Guide to Some Common Diatom Species from South Africa. WRC Report TT 282/07. 178 pl., Water Research Commission, Pretoria.

Taylor, J.C.; Janse van Vuuren, M.S. \& Pieterse, A.J.H. (2007b): The application and testing of diatombased indices in the Vaal and Wilge Rivers, South Africa. - Water SA 33: 51-59.

The European Parliament and the Council of the European UnION (2000): Directive 2000/60/EC of the European Parliament and of the Council of 23 October 2000 establishing a framework for Community action in the field of water policy. - Official Journal of the European Union L327: 1-73.

Tudesque, L.; Le Cohu, R.; Coste, M. \& Lange-Bertalot, H. (2015): Lacuneolimna gen. nov., Lacuneolimna zalokariae comb. nov. and Lacuneolimna novagallia spec. nov. (Bacillariophyceae) from the French Guiana diatom freshwater flora. - Phytotaxa 231: 19-30.

Wetzel, C.E.; Ector, L.; Van de Vijver, B.; Compère, P. \& ManN, D.G. (2015): Morphology, typification and critical analysis of some ecologically important small naviculoid species (Bacillariophyta). - Fottea 15: 203-234.

Zgrundo, A.; Lemke, P.; Pniewski, F.; Cox, E. J. \& Latala, A. (2013): Morphological and molecular phylogenetic studies on Fistulifera saprophila. - Diatom Res. 28: $431-443$

Supplementary material

the following supplementary material is available for this article:

Table S1. The main light microscopic morphological features of Sellaphora archibaldii and some similar small naviculoid diatoms.

This material is available as part of the online article (http:// fottea.czechphycology.cz/contents)

(C) Czech Phycological Society (2017)

Received February 1, 2016

Accepted August 15, 2016 